\title{
Development of Teaching Materials Based On Open- Ended Approach with Autograph Assistance to Improve Mathematical Creative Thinking Ability of Junior High School
}

\author{
Marlinda Yanti \\ Graduation Mathematics Education \\ Post \\ Universitas Negeri Medan \\ Indonesia \\ Yantimarlinda25@gmail.com
}

\author{
Hasratuddin \\ Mathematics Education \\ Universitas Negeri Medan \\ Indonesia
}

\author{
Pardomuan Sitompul \\ Mathematics Education \\ Universitas Negeri Medan \\ Indonesia
}

\begin{abstract}
Open ended approach is a learning approach that presents a problem that has more than one answer or settlement method. Open ended approach encourages students to develop creative ideas and mathematical mindset by remembering previous mathematical concepts, so that with the open-ended approach, students are expected to have a much better mathematical creative thinking ability. The purpose of this research is to analyze the improvement of students creative thinking ability by using learning materials developed through autograph assisted open-ended approach. This research is a development research using Thiagarajan 4D model with define stage, design, develop, an dessiminate. The subject of this research is Junior High School Swasta Imelda Medan. The teaching materials that will be developed in this study are learning tools that include Learning Implementation Plan (RPP), teacher book (BPG), Student book (BS) and, student worksheet (LAS) and creative thinking ability test. From results of trial I and II by using learning materials developed through autograph assisted open-ended approach effectively used in learning mathematics so that there is an increase in creative thinking ability of students.
\end{abstract}

Keywords-Development, Learning Materials, Creative Thinking Ability, Open-Ended Approach Autograph Assistance

\section{INTRODUCTION}

In the implementation of learning, the teacher must be able to prepare learning plans so that the mathematics material can be accepted by students. The learning process will run well if the teacher is able to design learning well, starting from learning plan tools, learning implemention in the classroom, to evaluating it. In carrying out this basic task alone, teachers still experience problems, such as in making learning devices, learning implemention in the classroom, and learning evaluation relative high. Making a lesson plan is a must for a teacher, because in the lesson plan contains important aspects of the teaching and learning process. These aspects include competencies to be achieved, ways to achieve, subject matter/material, interaction models, evaluation models, and etc.

Effendi (2008) states that teachers who experience learning problems in a class most likely will have problems such as: (1) Students are relatively difficult to take lessons and relatively difficult to do and collect tasks on time, etc; (2) Teachers have not been able to utilize and create learning media; (3) Utilization and use of time that is not in accordance with the RPP, especially for practice; (4) Infrastructure facilities that do not support the teaching and learning process; (5) The chosen learning method is still inappropriate.

In addition, according to Sugiantara (2003), in his research stated that student textbooks that are used as the dominant source presents formulas without providing opportunities for students to build their understanding of the material, lack of opportunities and means for students to interact and build their own understanding during the learning process.

As a result of the teacher's difficulty in develop of teaching materials that cause students to experience difficulties in understanding the material presented by the teacher, students regard mathematics material as a burden that must be remembered and memorized, and lack of meaning in everyday life. As a result students in the class cannot afford to be more active in learning mathematics.

Nehe, Surya, and Syahputra (2017) in their research stated that the ability to think creatively is a mental activity that is associated with sensitivity to the problem, pay attention to new information and ideas that are usually not with an open mind and can create relationships in solving problems.

In the research Mann, Chamberlin, and Graefe (2016) in his research stated that the importance of influence in 
creativity cannot be underestimated, because problem solving requires the right state of mind to be maximally productive in creative effort. So that mathematical creative thinking skills are needed in problem solving.

Therefore, the need for development of teaching materials that help to improve students' mathematical creative thinking skills. Development of teaching materials must be arrange based on the right learning model as well. The use of learning models that are not in accordance with the development of students will have an impact on the development stage of student learning. One step that can be done by the teacher to improve creative thinking skills is an open ended approach.

Shimada (1997) states that "Open ended approach is a learning approach that presents a problem that has more than one answer or settlement method". Open ended approach can provide opportunities for students to gain knowledge, experience finding, recognizing, solving problems with several techniques so that the way students are properly trained. Open ended approach encourages students to develop creative ideas and mathematical mindset by remembering previous mathematical concepts, so that with the open-ended approach, students are expected to have a much better mathematical creative thinking ability.

In addition, learning techniques that can be used in mathematics learning that provide opportunities for students to learn creative and more active are by learning techniques using computer technology. According to Erly (2013) the use of learning tools in the learning process assisted by technology significantly effectively improves student learning outcomes in mathematics materials such as the autograph application. Autograph is a software that direct its users to think creative in finding yourself about mathematical material. Autograph is designed to help teachers and students imagine medium-level mathematics using dynamically related objects.

Based on the description above, these problems are very influential on student learning results, so as to overcome these problems the researcher conducted a research which is the development of teaching materials based on open-ended approach with autograph assistance to improve creative thinking ability of Junior High School.

\section{RESEARCH METHOD}

This research is a development research used model of development of Thiagarajan, Semmel and Semmel device, that is 4-D model (define, design, develop, disseminate). This research was conducted to produce the necessary teaching materials which will then be tested in class. So that the product of this study is teaching materials (RPP, textbooks and
LKS) used open-ended approach with autograph assistance to improve creative thinking ability.

Subjects in this study were students of class VII Junior High School academic year 2017/2018. The object in this study was to look at the quality (valid, practical and effective) teaching materials developed used open-ended approach with autograph assistance on tangent circle material.

Instrument or data collection tool in this research is test. The test is used to measure students' creative thinking abilities. Furthermore, to see the effectiveness of teaching materials viewed from:

a. Student's learning completeness in classical, that is analyzed by considering that student is said to be complete if individual student value reaches $65 \%$, while a learning is said to have finished classically that if there is $85 \%$ of students who follow the test has been completed (Hasratuddin, 2015).

b. Analysis of achievement of learning objectives, to see the achievement of learning objectives each test item of mathematical creative thinking ability used the formula:

$$
T=\frac{\text { Total student scores for points in the i item }}{\text { The maximum number of points in the i item }} \times 100 \%
$$

The criteria are:

$0 \% \leq \mathrm{T}<75 \%$ : Learning objectives have not been achieved

$75 \% \leq \mathrm{T} \leq 100 \%$ : Learning objectives are achieved

c. Questionnaire responses of students were analyzed by calculating the percentage of many students who responded positively to each of the categories asked in the questionnaire by using the following formula:

$$
\text { PRS }=\frac{A}{B} \times 100 \%
$$

Information :

PRS : Percentage of many students who respon positively to each of the categories asked

A : Proportion of students who choose

B : Number of students (respondents)

To determine the achievement of learning objectives in terms of student responses, if the number of students who give a positive response is greater or equal to $70 \%$ (positive) of the many subjects studied for each trial. If $\geq$ $70 \%$ then the learning tools developed have fulfilled the effectiveness requirements 


\section{RESEARCH RESULT AND DISCUSSION}

Description of Stage of Material Development used openended approach with autograph assistance

The researcher conducted a research on development of teaching materials with 4-D development model (Four-D Model) proposed by Thiagarajan, Semmel and Semmel. The first stage begins with the define, the second stage is design, the third stage is development and the last stage is dissemination. The results of the development of such teaching materials can be described as follows:

\section{A. Definition Stage (define)}

\section{1) Final Beginning Analysis}

Based on observations on the teaching and learning process of teachers at Imelda Private Junior High School in Medan, shows that teachers still use the learning method used is still teacher-centered, so students are less active in the teaching and learning process. With student inactivity in the learning process, this causes a lack of students' mathematical creative thinking skills. Not only that, teachers also lack training in students 'creative thinking skills so that students' creative thinking skills are lacking.

\section{2) Student Analysis}

Analysis result of the academic ability of students Junior High School were classified as lacking. This can be seen from the results of the average mathematics score of students in the first semester of 50, while the KKM for mathematics is 70 . The teacher still uses the usual learning pattern, which explains the concept or procedure with a few questions and answers, giving examples of problems and giving practice questions. This results in students not being accustomed to contracting knowledge and not being creative because they are less active in learning. Learning tools used so far have not paid attention to student analysis, therefore teaching materials were developed that were adjusted to the character of students in the hope that the quality of mathematics learning could improve.

\section{3) Concept Analysis}

The subject matter used in this research is tangent circle material for Junior High School class VIII with reference to Curriculum 2013.

\section{4) Task Analysis}

The results of the task analysis performed were the tasks of the students at the time of learning by using teaching materials developed, that is to analyze the properties of the tangents of the circle, draw tangents of circles and tangents of alliances using the term and autograph software, and solve the problem of tangents in various ways.

\section{5) Formulation of Learning Objectives}

The learning objectives to be achieved by students are based on the basic competencies of the tangent material of the circle, namely:

1. Describe the outline of the outer alliance and fellowship in two circles and how to paint it

2. Resolve problems related to tangent circles communion outside and in two circles

Based on these basic competencies, the learning objectives that must be achieved by students are:

1. Understanding the concept of tangent circle

2. Paint the tangent circle

3. Calculate tangents of circles

4. Understand the position of two circles

5. Understand the concept of tangents of two circles

6. Paint tangents in two circles

7. Calculate the tangents of alliances in two circles

8. Paint tangents out of two circles

9. Calculate the tangent to the outer circle of two circles

10. Resolve problems related to circles and tangents of two circles.

\section{B. Design Stage (design)}

\section{1) Preparation of the Test}

The test used is a test of mathematical creative thinking ability.

2) Selection of Media and Tools

The media used in this study is computer media in the form of autograph software

\section{3) Format Selection}

The textbook format refers to the rules of BSNP (National Education Standards Agency). Textbooks and LKS are colored so that students will be interested and motivated to learn.

\section{4) Initial Design}

In the initial design stage, the initial draft of instructional materials in the form of Learning Implementation Plan (RPP), Textbook, and LKS for 4 (four) meetings, mathematical creative thinking test, scoring guidance, and answer. All the results of this design stage are here in after referred to as draft 1.

\section{Development Stage}

The results of the define and design stage resulted in the initial design of a learning tool called draft 1. After the learning tool based on realistic mathematical approach designed in the form of draft 1 , the validity test of the expert review and field trial was conducted. 


\section{1) Validation Results}

Before learning tools and research instruments are piloted, first learning tools and research instruments are validated to five validators including experts in the field. From the validation results, the learning device criteria and research instruments developed are "valid" and can be used with small revisions. Furthermore, the test of students' mathematical creative thinking ability, tested in the class outside the sample, then tested the validity and reliability.

\section{Trial I}

Once the learning device developed has met the valid criteria. Then the next learning device in the form of draft II is tested in place of research that is test I conducted in class VIIIC Junior High School. The result of analysis of trial data I is instructional device not yet effective, because there are still some indicator of effectiveness that have not reached that is result of classical completeness mathematical creative thinking ability and analysis of achievement of learning objectives on trial I can be seen in Table 1.

TABLE 1. Description of Results of Ability of Student Mathematical Creative Thinking Ability in Trial I

\begin{tabular}{|l|c|}
\hline Information & $\begin{array}{c}\text { Mathematical creative thinking } \\
\text { Posttest }\end{array}$ \\
\hline Highest score & 92 \\
\hline Lowest score & 63 \\
\hline Average & 77,94 \\
\hline Completeness Percentage & $80 \%$ \\
\hline
\end{tabular}

Based on Table 1 it can be seen that the average class for the test of mathematical creative thinking ability in test 1 is 77,12 with the percentage of students' learning completeness in classical that is $80 \%$ from 30 students. This states that the student has not fulfilled the classical thoroughness value because a learning is said to have finished classically that if there is $85 \%$ of students who follow the test has been completed.

In addition, analysis of achievement of learning objectives on trial I is described briefly in Table 2.

TABLE 2. Description of Results of Analysis Of Achievement of Learning Objectives on Trial I

\begin{tabular}{|l|c|c|}
\hline \multirow{2}{*}{ Learning Objectives } & \multicolumn{2}{|c|}{$\begin{array}{c}\text { Mathematical Creative Thinking } \\
\text { Ability }\end{array}$} \\
\cline { 2 - 3 } & $\begin{array}{c}\text { Achievement } \\
\text { of Learning } \\
\text { Objectives }\end{array}$ & Information \\
\hline \hline $\begin{array}{l}\text { Students are able to determine the } \\
\text { properties of the tangent circle }\end{array}$ & $81,25 \%$ & achieved \\
\hline $\begin{array}{l}\text { Students are able to paint tangents } \\
\text { of circles and tangent alliances }\end{array}$ & $70,42 \%$ & not achieved \\
\hline $\begin{array}{l}\text { Students are able to calculate exact } \\
\text { length of external tangent alliance }\end{array}$ & $57,29 \%$ & not achieved \\
\hline $\begin{array}{l}\text { Students are able to calculate exact } \\
\text { length of internal tangent alliance }\end{array}$ & $75,63 \%$ & achieved \\
\hline
\end{tabular}

In accordance with the criteria for the achievement of learning objectives, said learning objectives are achieved with criteria $\geq 75 \%$ of the maximum score of each item. Thus based on Table 2, the achievement of learning objectives in test I that is on the posttest results mathematical creative thinking ability has been achieved for number 1 items and items number 4 while what has not been achieved is item number 2 and item number 3 .

Based on the results of analysis and test $\mathrm{I}$, it is necessary to revise some component of teaching materials developed in the hope that learning tools can improve students' mathematical creative thinking ability.

\section{Trial II}

After making a revision in draft II, further improvements are made to produce learning devices that meet the good effectiveness. The result of revision in trial I produced draft III which will be tested on VIII-D Junior High School students. These 2 trials were conducted four times in accordance with the learning implementation plan (RPP) that has been developed. Test 2 was conducted to measure the effectiveness of learning tools (draft III) developed used open ended approach with autograph assistence aimed at improving students' mathematical creative thinking ability. Overall, the classical completeness level of students' mathematical creative thinking ability in trial II can be seen in Table 3 .

TABLE 3. Description of Results of Ability of Student Mathematical Creative Thinking Ability in Trial II

\begin{tabular}{|l|c|}
\hline Information & $\begin{array}{c}\text { Mathematical creative } \\
\text { thinking Posttest }\end{array}$ \\
\hline Highest score & 92 \\
\hline Lowest score & 63 \\
\hline Average & 77,94 \\
\hline $\begin{array}{l}\text { Completeness } \\
\text { Percentage }\end{array}$ & $86,67 \%$ \\
\hline
\end{tabular}

Based on Table 3 it can be seen that the average class for the test of mathematical creative thinking ability in trial II is 77,94 with the percentage of students' learning completeness classically that is $86,67 \%$ from 30 students. It is stated that the students have fulfilled the classical value.

Furthermore, the implementation of learning, student response has been achieved and positive. Likewise, the achievement of learning objectives in trial II for posttest results mathematical creative thinking skills have been achieved. Thus it can be concluded that the learning device developed using open ended approach with autograph assistence in trial II which is a revision of trial I has met the quality of effective learning tools. 


\section{Disseminate Stage}

Teaching materials develop using open ended approach with autograph assistence in the deployment stage are done in a limited way only in partner schools only Junior High School. After the final teaching materials, the developed teaching materials are disseminated to be used in the next semester in tangents of circle materials.

1. Improvement of Ability of Student Mathematical Creative Thinking Ability by Using Teaching Material developed open ended approach with autograph assistence

The results of the analysis of the improvement of students 'mathematical creative thinking ability in the trial I and trial II showed that the average students' mathematical creative thinking on the posttest results of the trial I was 73.50 increasing to 77.94 in the trial II. This is in according with the data analysis of students 'mathematical creative thinking ability, namely the improvement of mathematical creative thinking abilities seen from the average posttest results of trials I and II thus it is known that there is an increase in the average value of students' mathematical creative thinking skills 4.44 .

Furthermore, a description of the improvement of students 'mathematical creative thinking skills used teaching materials based on open ended approach with autograph assistence developed in experiment I and trial II for each indicator of students' creative mathematical thinking can be seen in Table 4.

TABLE 4. Average Student Mathematical Creative Thinking Ability for Each Indicator

\begin{tabular}{|c|c|c|c|}
\hline \multirow{2}{*}{$\begin{array}{c}\text { Mathematical } \\
\text { Creative Thinking } \\
\text { Indicator }\end{array}$} & Trial I & Trial II & enhancement \\
\cline { 2 - 4 } & 3,37 & 3,53 & 0,16 \\
\hline Fluency & 2,82 & 2,87 & 0,05 \\
\hline Flexibility & 2,91 & 3,14 & 0,23 \\
\hline Originality & 2,63 & 2,98 & 0,35 \\
\hline Elaboration & & & \\
\hline
\end{tabular}

Based on Table 4, it can be seen that the students' mathematical creative thinking ability was increased from the first trial to the second trial for each indicator. The Fluency indicator is 0.16 ; for the Flexibility indicator of 0.05 ; for the Originality indicator of 0.23 ; and for the Elaboration indicator of 0.35 . For more details can be seen in Figure 1 .

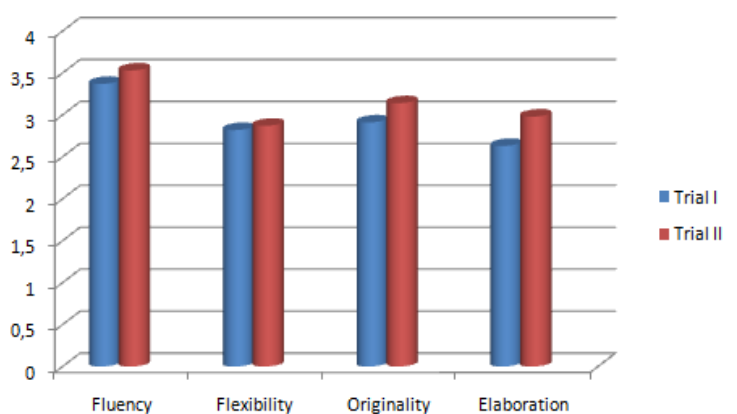

Fig 1. Average Mathematical Creative Thinking Ability for Each Indicator

Based on Table 4 and Figure 1 it can be seen that students' mathematical creative thinking ability from trial I to trial II is seen from the total average score and the average value of each indicator has increased through the application of learning devices based on an open ended assisted autograph approach developed. So, it can be said that the teaching materials based on developed using open ended approach with autograph assistence have an impact on improving the ability of mathematical creative thinking both in terms of the average test results of students' mathematical creative thinking skills as well as on each indicator of mathematical creative thinking ability.

\section{CONCLUSION}

Based on the results of data analysis and research implementation learning used teaching materials based on an open ended approach with autograph assistence to improve students' mathematical creative thinking ability, he researchers obtained the following conclusions:

1. The validity of developed learning devices is included in the valid category.

2. Teaching materials developed based on open ended approach with autograph assistence meet the criteria effectively. Effective criterion is observed from: (1) student's learning completeness has been classically achieved in trial II that is equal to $86,67 \%$; (2) the achievement of learning goals has also met the criteria of achievement; and (3) positive student response to the components of learning devices and learning activities developed.

3. By using learning tools based on autograph-assisted open ended approach, students' mathematical creative thinking ability increases from trial I to trial II.

\section{REFERENCES}

[1] Effendi. 2008. Analisis Kualifikasi dan Kompetensi Profesi Guru serta Upaya Pengembangannya dalam Menyikapi UU Guru-Dosen. Pendidikan Dasar dan Menengah. Malang

[2] Sugiantara, G. P. A; Sadra, W; dan Suparta, N. 2013. Pengembangan Perangkat Pembelajaran Matematika Realistik dengan Peta Konsep Pada Materi Trigonometri Di Kelas XI SMK. e-Journal Program 
Pascasarjana Universitas Pendidikan Ganesha Program Studi Matematika; Volume 2 Tahun 2013

[3] Nehe, M. Surya, E; \& Syahputra, E. 2017. Creative Thinking Ability to Solving Equation and Nonequation of Linear Single Variable in VII Grade Junior High School. IJARIIE-ISSN(O)-2395-4396: Vol-3 Issue-2 2017

[4] Mann, E. L; Chamberlin, S. A; Graefe, A. K. 2016. The Prominence of Affect in Creativity: Expanding the Conception of Creativity in Mathematical Problem Solving. Springer International Publishing Switzerland 2016. Mathematics Education, DOI 10.1007/978-3-319. 38840-3_5

[5] Shimada, S. (1997). The Significance of an Open-Ended Approach. Dalam J. P. Becker dan S. Shimada(ed) The Open-Ended Approach: A New Proposal for Teaching Mathematics. NCTM. 1 - 9

[6] Erly, S. 2013. Pengembangan Bahan Ajara Matematika Berbasis ICT pada Model Pembelajaran JJIGSAW Materi Differensial. Fakultas MIPA. IKIP Semarang

[7] Hasratuddin. 2015. Mengapa Harus Belajar Matematika?. Medan: Perdana Publishing

[8] Fauzi, KMS Muhammad Amin (2002). Pembelajaran Matematika Realistik pada Pokok Bahasan Pembagian di Sekolah Dasar. Tesis. Program Pasca Sarjana Universitas Negeri Surabaya, Surabaya.

[9] Trianto. 2011. Mendesain Model Pembelajaran Inovatif-Progresif. Jakarta: Kencana Prenada Media Goup. 